\title{
Biodiversity in South East Asia: an overview of freshwater sponges (Porifera: Demospongiae: Spongillina)
}

\author{
Renata MANCONI,${ }^{*}$ Nisit RUENGSAWANG,${ }^{2}$ Viengkorn VANNACHAK,${ }^{3}$ Chutima HANJAVANIT,${ }^{4,5}$ \\ Narumon SANGPRADUB ${ }^{4,5}$ Roberto PRONZATO ${ }^{6}$
}

\begin{abstract}
${ }^{1}$ Dipartimento di Scienze della Natura e del Territorio, Università di Sassari, Via Muroni 25, 07010 Sassari, Italy; ${ }^{2}$ Division of Biology, Faculty of Science and Technology, Rajamangala University of Technology Krungthep, 2 Nanglinchee road, Bangkok, 10120 Thailand; ${ }^{3}$ Department of Biology, Faculty of Science, National University of Laos, Vientiane, 7322 Laos; ${ }^{4}$ Applied Taxonomic Research Center, Khon Kaen University, Khon Kaen, 40002 Thailand; ${ }^{5}$ Department of Biology, Khon Kaen University, Khon Kaen, 40002 Thailand; ${ }^{6}$ Dipartimento di Scienze della Terra, dell'Ambiente e della Vita, Università di Genova, Corso Europa 26, 16132 Genoa, Italy *Corresponding author: r.manconi@uniss.it
\end{abstract}

\begin{abstract}
Despite the fact that South East (SE) Asia is considered as a biodiversity hotspot, knowledge of sessile invertebrates such as freshwater sponges (Porifera: Haplosclerida: Spongillina) in this region is poor and scarcely reported. For this synopsis, diversity and distribution of SE Asian inland water sponges is reported on the basis of available literature and a recent biodiversity assessment of the Lower Mekong basin. A diagnostic key of families/genera from SE Asia is provided together with Light Microscopy and Scanning Electron Microscopy protocols to prepare the basic spicular complement for taxonomic identification. So far, SE Asian freshwater sponges consist of widespread and/or endemic species belonging to the families Metaniidae, Potamolepidae, and Spongillidae. The highest diversity is recorded from Indonesia, Philippines, Thailand, and Myanmar, respectively. Data from the other countries are necessary for our understanding of their diversity and distribution. Biodiversity in SE Asia is strongly underestimated, as indicated by recent new records and the discovery of new species of freshwater sponges in Thailand. Further investigations should reveal higher values of taxonomic richness, highlighting biogeographic patterns at the family/genus/species levels. A cooperative network involving Thai, Laotian and Italian researchers, was set up to contribute and fulfil knowledge on taxonomy, ecology and biotechnological potentialities of these neglected filter feeders, playing a key role in water purification and biomass production in both lentic and lotic ecosystems in the tropics.
\end{abstract}

Key words: Taxonomic richness, Oriental region, biogeographic patterns, conservation.

Received: April 2013. Accepted: June 2013.

\section{INTRODUCTION}

The earliest naturalists grouped freshwater sponges, and in general Porifera, with plants because of their sessile nature, greenish-brownish colour, and growth form Spongilla lacustris (Linnaeus, 1759) was described (as Spongia lacustris) by Linnaeus (1759) as repens, fragilis, ramis teretibus obtusis (creeping, fragile, with cylindrical branches showing swellings at their ends) in the second volume of Plantae of the Systema Naturae, and the type material was preserved in the Linnean Herbarium (Manconi and Pronzato, 2000). Sponges were not recognised as animals until 1765, when the internal water current was first described, and only in 1875 , Huxley proposed the complete separation of sponges from other Metazoa (Gaino, 2011).

At present, sponges are considered as basal Metazoa, lacking true organs and a nervous system. Their body architecture, usually displaying an irregular symmetry, is very plastic and characterised by continuous morphogenesis. The bauplan of sponges does not match completely the concepts of the colony or the individual. It matches better the concept of modular organisms because of their ability to alter body architecture in time and space (Pronzato and Manconi, 1994a, 1994b). The functional units (ramets) of these modular animals are clearly evident during freshwater sponge cryptobiosis (aestivation or hibernation by resting bodies) and modules (gemmules) can be isolated from one another, unlike those of adult freshwater sponges (Pronzato and Manconi, 1994a, 1994b, 1995; Manconi and Pronzato, 2013).

Sponges are suitable microhabitats and are associated with or host bacteria, unicellular algae, protists, hydrozoans, turbellarians, nematodes, oligochaetes, leeches, bivalves, gastropods, decapods, amphipods, copepods, ostracods, hydracarins, and bryozoans, as well as several orders/families of insects encompassing the typical spongillaflies together with fishes and amphibians. Sponges have been reported to be fed upon by some freshwater turtles, ducks, fish and insects where spicules were found in stomach contents (Pronzato and Manconi, 2001; Manconi and Pronzato, 2008). 
Porifera are primary marine invertebrates which have colonised continental water since the Palaeozoic as indicated by the Permo-Carboniferous spiculites of freshwater sponges (Haplosclerida: Spongillina) (Schindler et al., 2008). Although records are discontinuous, Mesozoic remains date back to the Upper Jurassic and Lower Cretaceous, but most fossils refer to the Eocene, Miocene, Pliocene, and the Pleistocene (Pisera and Saez, 2003; Pisera, 2004; Schindler et al., 2008). Fossil evidence, together with the ability of some recent taxa of Spongillina to live in estuaries and coastal water bodies with variable salinity (Annandale, 1915; Evans and Kitting, 2010), suggests the occurrence of the invasion of inland waters by sponges from coastal brackish waters of epicontinental and/or enclosed seas.

Systematics and phylogeny of freshwater sponges (Porifera: Haplosclerida: Spongillina) are based on morphology, anatomy, and cytology together with reproductive, developmental, and molecular biology. A morphological dataset of macro- and micro-morphotraits is diagnostic up to the genus and species level (Manconi and Pronzato, 2002).

The monophyletic status of Spongillina, based on classic taxonomic techniques, has been shown to be robust from recent syntheses that focused on comparative analyses of morphotraits (Manconi and Pronzato, 2002, 2009). This is supported in part by molecular approaches (Meixner et al., 2007; Erpenbeck et al., 2011). The resolution power of molecular analyses in Porifera is not, however, fully diagnostic and needs to be improved and compared with morphological analyses.

Plesiomorphic morphotraits, e.g. skeletal architecture, monaxial spicules, gemmules and gametes together with larval (parenchymella) structure suggest that Spongillina are allied to coastal marine Haplosclerina (order Haplosclerida). Apomorphies of the Spongillina are at the level of both sexual and asexual propagules such as swimming parenchymellas type III provided by choanocyte chambers, canals, and spicules as well as gemmules displaying a highly diverse architecture.

Present knowledge on the biodiversity and biogeography of freshwater sponges from Southeast (SE) Asia are based mostly on few records and scattered papers. Indeed, exhaustive monographies are scarce and at present only a few biologists focus on this region (Bowerbank, 1863; Carter, 1881; Potts, 1887; Weber, 1890; Weltner, 1895, 1913; Annandale, 1909, 1911, 1918; Arndt, 1926; Vorstman, 1927, 1928; Gee, 1930, 1931, 1932a, 1932b; Schröder, 1935; Penney, 1960; Penney and Racek, 1968; Racek, 1969; Soota, 1991; Volkmer-Ribeiro and Costa, 1993; Banarescu, 1995; Manconi and Pronzato, 2002, 2007, 2008, 2009; Masuda, 2004; Ohtaka et al., 2011).

Although SE Asia is considered as a biodiversity hotspot (Myers et al., 2000), knowledge of freshwater sponges in this area is poor and scarcely reported. In the present study, we compile a report on the diversity and distribution of the SE Asian freshwater sponges, based on available literature and a recent biodiversity assessment of the Lower Mekong basin in Thailand.

\section{METHODS}

Bibliographic investigations were performed in depth to ascertain previous records in the eastern area of SE Asia vs global taxonomic assessments.

New collections of sponges were carried out during visual census by wading, snorkelling and scuba diving in the Pong river (Mekong Hydrographic basin, Khon Kaen province, NE Thailand). Sampling was easier during low water seasons when dried sponges and/or gemmular carpets can be found on substrata although they can be easily overlooked in this life cycle phase. Species-level identification required collection of gemmules from the basal portion of the sponge body or sometimes from the surface of hard substrata where they adhere. Gemmules, however, may be absent in some phases of the sponge life cycle.

The most representative specimens were photographed in vivo and/or in situ, preserved by air drying, ethanol $/$ methanol, or freezing and registered in a voucher collection each with a label reporting basic collection data (locality, date, collector name). It is not necessary to collect always entire specimens: representative body fragments bearing gemmules is enough. Entire sponges (possibly with a part of their substratum), however, are necessary for museum collections. A set of key macroand micro-morphological diagnostic characters considered for identification at the genus and species levels is focused on growth form, consistency, colour, surface traits, topographic distribution of inhalant and exhalant apertures, architecture of ectosomal and choanosomal skeleton, topographic distribution and traits of skeletal megascleres, microscleres, and gemmules, gemmular architecture (foramen, gemmular cage, gemmular theca, spatial arrangement of pneumatic layer and spicules), and gemmuloscleres morphology (Manconi and Pronzato, 2002; but see the present diagnostic key of genera from SE Asia).

To characterise morphotraits, representative fragments of sponges were dissected for light microscopy (LM) and/or scanning electron microscopy (SEM) observation. A rapid protocol to prepare preliminarily slides of spicular complement is based on the digestion of organic matter of skeleton and gemmules in a drop of boiling $65 \%$ nitric acid on a slide. To obtain perfectly cleaned spicule preparations for SEM observation and LM slides for a voucher collection, sponge fragments were dissolved in boiling $65 \%$ nitric acid or in sodium hypochlorite (ambient temperature) in test tubes and then suspended in water. To achieve total sedimentation of the lighter, smaller 
spicules, they were suspended and repeatedly rinsed with distilled water and then dehydrated in graded ethanol series, with a gap of 15-20 min between successive washing (Manconi and Pronzato, 2000). Spicules suspended in alcohol have been poured from tubes with a slow movement to leave the deposit of spicules in $0.5 \mathrm{~mL}$ of the medium within the tube before dropping some suspended spicules on slides for LM and SEM analysis (Manconi and Pronzato, 2000). After the total evaporation of alcohol, each slide fragment was fixed on a stub with silver glue drops. The presence of a glass substratum under the spicules gives the best results as a perfectly black background in the SEM photographs. Dry body fragments, dissociated spicules, entire gemmules, and their cross-sections were sputter-coated with gold and observed under SEM (Manconi and Pronzato, 2000). Morphometric data of diagnostic traits were performed by LM and/or SEM. To characterise potential new species, approximately 50 spicules for each diagnostic spicular type were measured for representative specimens of recorded species. Comparative analyses were performed on new voucher collections $v s$ materials from several historical collections and original descriptions.

\section{RESULTS}

Southeast Asia is not a biogeographic region (or subregion) but a geographic entity of convenience which excludes India, Southwestern China and Wallacea (Fig. 1).

The freshwater sponge species recorded from SE Asia add up to a total of 26 , belonging to 12 genera with a total of 40 records (Fig. 1, Tabs. 1 and 2). The most represented genus is Eunapius Gray, 1867 with five species (Fig. 1, Tab. 2). The most reported species is Eunapius carteri (Bowerbank, 1863) with five records (Figs. 1 and 2; Tab. 2). A well represented genus is Radiospongilla Penney and Racek, 1968 with four species, three of which have been recorded two times (Fig. 1, Tab. 2). Other, relatively common species, belong to the widespread genus Trochospongilla Vejdowsky, 1883 with Trochospongilla latouchiana Annandale, 1907 (four records), and the Asiatic-Australian genus Umborotula Penney and Racek, 1968 with the Umborotula bogorensis (Weber, 1890) (three records) (Fig. 1, Tab. 2). Indeed, a high number of species ( 18 out of 26 ) is reported only once from this area. Moreover, in some cases the findings are very old and not confirmed by recent field campaigns (Fig. 1; Tab. 2).

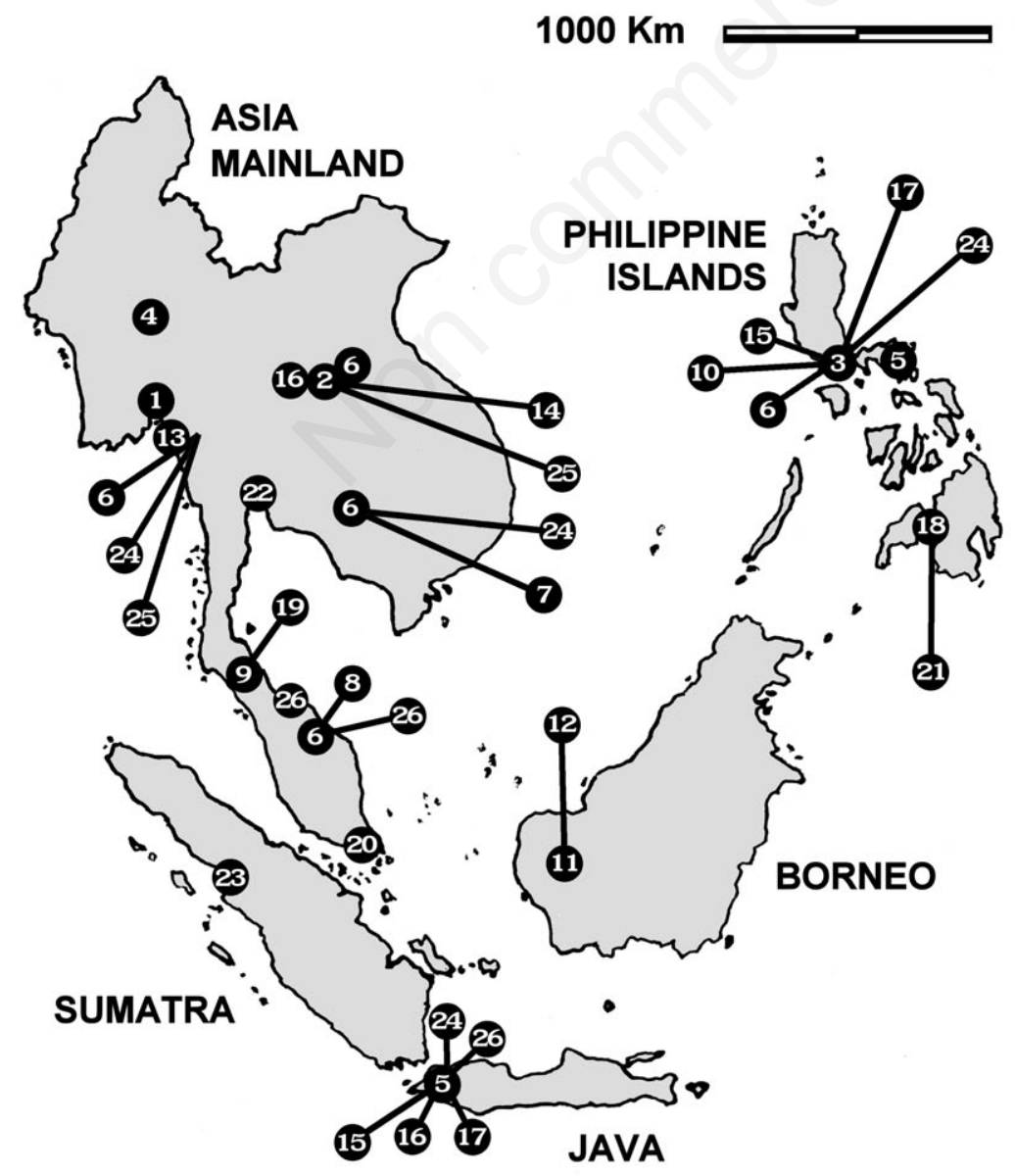

Fig. 1. Distribution of Spongillina species in freshwater of the Southeast Asia. Numbers refer to records in the map. 1, Corvospongilla burmanica; 2, Corvospongilla siamensis; 3, Dosilia plumosa; 4, Ephydatia fluviatilis; 5, Ephydatia fortis; 6, Eunapius carteri; 7, Eunapius crassissimus; 8, Eunapius fragilis; 9, Eunapius potamolepis; 10, Eunapius tinei; 11, Metania pottsi; 12, Metania vesparia; 13, Metania vesparioides; 14, Oncosclera asiatica; 15, Radiospongilla cerebellata; 16, Radiospongilla crateriformis; 17, Radiospongilla indica; 18, Radiospongilla philippinensis; 19, Spongilla alba; 20, Spongilla sp.; 21, Stratospongilla clementis; 22, Stratospongilla indica; 23, Stratospongilla sumatrana; 24, Trochospongilla latouchiana; 25, Trochospongilla phillottiana; 26, Umborotula bogorensis. 
Tab. 1. Check-list (39 species, 12 genera, 3 families) of Spongillina (Porifera: Haplosclerida) of the Oriental region.

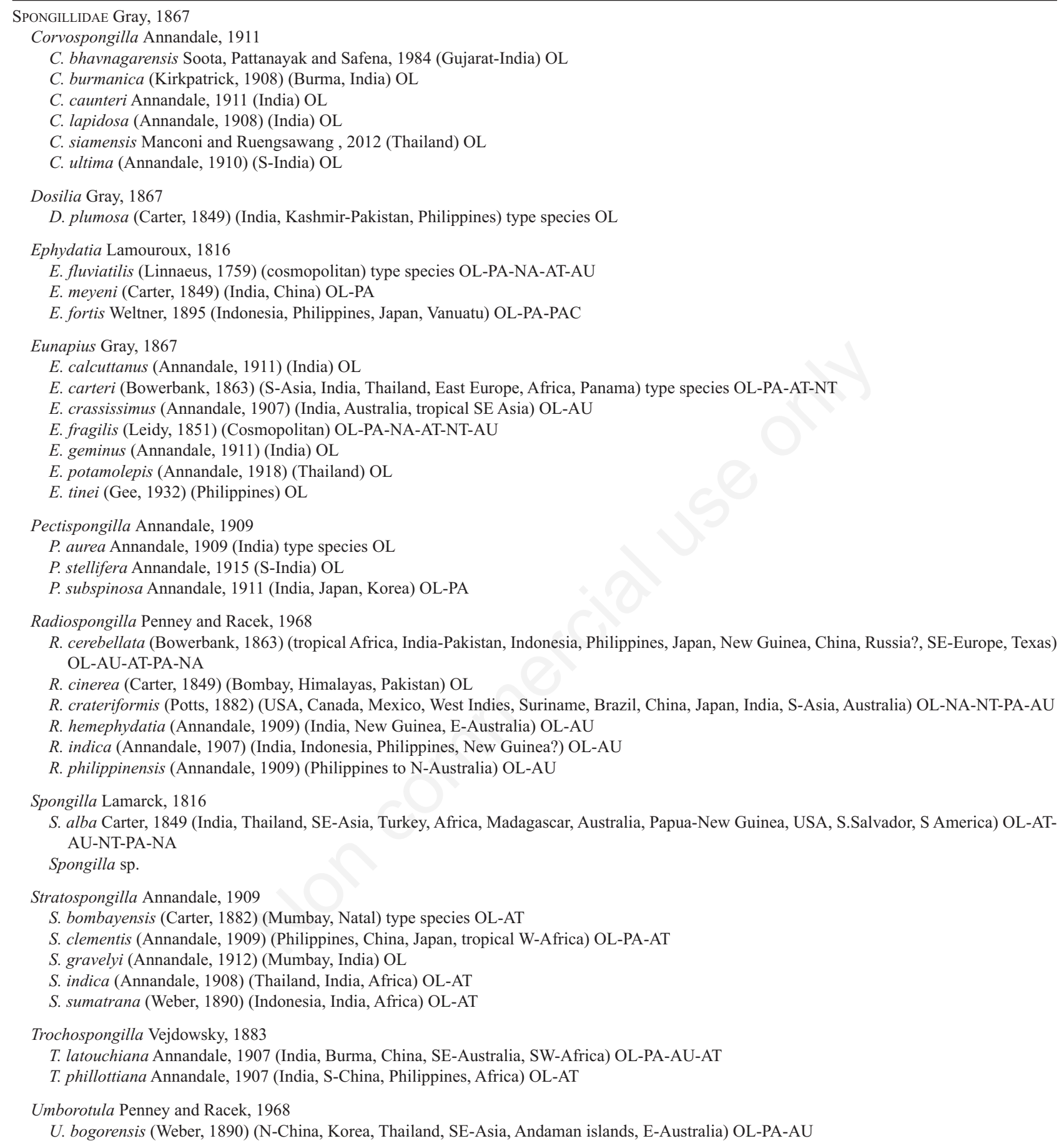

METANIIDAE Volkmer-Ribeiro, 1986

Metania Gray, 1867

M. pottsi (Weltner, 1895) (Congo basin, Angola, Borneo, Indonesia) OL-AT

M. vesparia (von Martens, 1868) (Borneo, Indonesia, Australia) OL-AU

M. vesparioides (Annandale, 1908) (Tenasserim, Burma, Australia) OL-AU

PotAmolePidAe Brien, 1967

Oncosclera Volkmer-Ribeiro, 1970

O. asiatica Manconi and Ruengsawang, 2012 (Thailand) OL

OL, Oriental region [modified and updated from Manconi and Pronzato (2007)]; PA, Palaearctic region; NA, Nearctic region; AT, Afrotropical region; AU, Australian region; PAC, Pacific islands; NT, Neotropical region; S, South; SE, Southeast; E, East; N, North; W, West; SW, Southwest. 
Only four species are considered endemic to SE Asia, namely three from Thailand [Corvospongilla siamensis Manconi and Ruengsawang, 2012, Eunapius potamolepis (Annandale, 1918), and Oncosclera asiatica Manconi and Ruengsawang, 2012] and one [Eunapius tinei (Gee, 1932)] from the Philippines (Figs. 3 and 4).

Among the 26 recorded species only 4 were recorded from both continental and insular freshwater of SE Asia, indeed 13 species are present exclusively in continental freshwater, whereas 9 were recorded exclusively from islands (Fig. 1, Tab. 2).

At the level of biogeographic regions, the freshwater sponge species known at present for the Oriental region are 39 (Tab. 1) with a notably high number of endemics (42.5\%) (Manconi and Pronzato, 2013). The latter values slightly differ from what reported by Manconi and Pronzato $(2007,2008)$ as consequence of taxonomic revisions, new records and/or discovery of new species. As for biogeographic patterns at species level, they range from endemic sensu stricto (one water body) or endemic sensu lato (large hydrographic basins, i.e. Mekong), to widespread (two-three geographic regions), up to apparently cosmopolitan.

In contrast, the value of endemicity is higher in the Indian Subregion ( $c a .45 \%$ ) harbouring 10 endemic species out of 23 recorded species (C. bhavnagarensis, C. caunteri, C. lapidosa, C. ultima, E. calcuttanus, E. geminus, P. aurea, P. stellifera, R. cinerea, S. gravelyi) (Annandale, 1911; Soota, 1991; Manconi and Pronzato, 2007, 2013).

The Spongillina species of SE Asia share gross morphological characters, typical of all freshwater sponges. Three morphological characters distinguish the habitus of freshwater sponges during their life cycle, namely the sessile growing adult (sponge-like), the planktonic short-life swimming larvae, and the dormant gemmules (restant body/propagule) (Manconi and Pronzato, 2013). The growth form of adults (active sponges) ranges from thin crusts in irregular patches strictly adhering to the substratum to massive cushions to bush-like (Figs. 3 and 5); more rarely they may also display variably erected finger-like to branching and arborescent growth forms. Dimensions are variable from a few millimetres to more than one metre in diameter. Body consistency is from soft, to fragile to very hard (stony) according with the amount of spongin in the skeleton. A wide range of colours are displayed, from white to greenish or brilliant emerald green, or greyish to dark brown and black. The colours result from sponge pigments, or symbiotic bacteria and algae, or englobed detritus. All these characters are largely not species-specific and are strictly related to environmental conditions, seasonal rhythms and/or life cycle phases.

The habitus of SE Asia freshwater sponges during seasonal dormancy is very different from that of the active sponges, i.e. as gemmules (small spherules up to over 1 $\mathrm{mm}$ in diameter; Fig. 2d) adhering to hard substrata, floating at the water surface, or within the old skeleton of the sponges. Morphological characters of gemmules are species-specific, diagnostic at genus/species level and therefore fundamental for taxonomic identification.

As for sexual reproduction, viviparity is the rule, and larvae are brooded as suboval, soft, whitish bodies protected within the mother sponge body up to the completion of the larval development (Manconi and Pronzato, 2013). During late sexual reproductive phases of the life cycle, larvae were observed in recently studied species from SE Asia only after sampling, swimming just during releasing from the oscules in the excurrent water flux, or brooded larvae as suboval, soft, whitish bodies protected within sponge bodies up to the complete development.

The natural resource represented by freshwater sponges have been used since ancient times (Neolitic) by humans, and at present some African and Amazonian populations produce ceramics tempered by siliceous sponge spicules (Manconi and Pronzato, 2013). Other practical uses are in the field of cosmetics and medicines. For example, dried spongillids were used in the $19^{\text {th }}$ century by Russian young ladies to scrub their faces to have rosy cheeks. Some cosmetics today exploit the scrubbing action of siliceous spicule powder, and recently this application was patented in the United States in the field of dermatology (Manconi and Pronzato, 2008, 2013). In the $17^{\text {th }}$ century, Samuel Hahnemann enclosed freshwater sponges (as Spongilla fluviatilis and Spongia palustris) in his Materia Medica as a homeopathic remedy for psoriasis with the common pre-linnean name of Badiaga (Manconi and Pronzato, 2013). Spongilla lacustris was also used in China for more than 500 years as a traditional medicine for reinforcing the kidney and supporting yang (aphrodisiac), although the chemical research on this species is poor (Hu et al., 2009; Manconi and Pronzato, 2013). Unfortunately, the exact identification (genus/species) of the sponges used as cosmetics and medicines in both the past and present is questionable because of inadequate taxonomic expertise.

As for indicators of palaeoenvironmental changes, freshwater sponges spicule remains (spiculites bed) play a key role in sediment analysis in lake beds and soils. The time interval needed for the formation of a spiculite of a few centimetres in thickness is estimated to have ranged from years to decades (Schindler et al., 2008). Variations in species composition and amount of siliceous microfossils (sponges spicules and diatoms-diatomites) are indicators of water quality changes and past salinity conditions (Manconi and Pronzato, 2008, 2013).

Freshwater sponge spicules are at present considered a potential agent of severe ocular disease among children swimming or diving underwater in water bodies rich of sponge assemblages. Risk factors include dislodging of 
Tab. 2. Taxonomic richness (genera, species) and endemic taxa of Spongillina from continental and insular areas of Southeast Asia, on the basis of forty recent and old records.

\begin{tabular}{|c|c|c|c|c|c|c|c|}
\hline Genera & Species & Records & Species validation & $\begin{array}{l}\text { SE-Asia } \\
\text { endemics }\end{array}$ & Continental & Insular & Remarks \\
\hline \multirow[t]{2}{*}{$\begin{array}{l}\text { Corvospongilla } \\
2 \text { species }\end{array}$} & C. burmanica & 1 & $\begin{array}{l}\text { Penney and Racek (1968); Manconi and } \\
\text { Pronzato (2004, 2007); Manconi et al. (2012) }\end{array}$ & & 1 & & $\begin{array}{l}\text { Scanty data; needs } \\
\text { revision }\end{array}$ \\
\hline & C. siamensis & 1 & Ruensawang et al. (2012) & Thailand & 1 & & Recently described \\
\hline $\begin{array}{l}\text { Dosilia } \\
1 \text { species }\end{array}$ & D. plumosa & 1 & $\begin{array}{l}\text { Penney and Racek (1968); Manconi and } \\
\text { Pronzato (2007) }\end{array}$ & & 1 & & $\begin{array}{l}\text { Recent detailed } \\
\text { description in } \\
\text { Jakhalekar and } \\
\text { Ghate (2013) }\end{array}$ \\
\hline \multirow[t]{2}{*}{$\begin{array}{l}\text { Ephydatia } \\
2 \text { species }\end{array}$} & E. fluviatilis & 1 & Manconi and Pronzato (2007); Manconi (2008) & & & 1 & $\begin{array}{l}\text { Common worldwide } \\
\text { needs revision; } \\
\text { potential species } \\
\text { complex }\end{array}$ \\
\hline & E. fortis & 2 & $\begin{array}{l}\text { Penney and Racek (1968); Manconi and } \\
\text { Pronzato (2007) }\end{array}$ & & & 2 & $\begin{array}{l}\text { High variable } \\
\text { morphology; needs } \\
\text { revision }\end{array}$ \\
\hline
\end{tabular}

Eunapius

5 species

E. carteri

5

Penney and Racek (1968); Manconi and Pronzato $(2002,2007,2009)$

\begin{tabular}{|c|c|c|c|c|c|c|c|}
\hline & \multirow{2}{*}{ E. crassissimus } & & & & & \\
\hline & & 1 & $\begin{array}{l}\text { Penney and Racek (1968); Manconi and } \\
\text { Pronzato (2007) }\end{array}$ & & 1 & & Easily identifiable \\
\hline & E. fragilis & 1 & $\begin{array}{l}\text { Penney and Racek (1968); Manconi and } \\
\text { Pronzato }(2007,2009)\end{array}$ & & 1 & & $\begin{array}{l}\text { Widespread; potential } \\
\text { species complex }\end{array}$ \\
\hline & E. potamolepis & 1 & $\begin{array}{l}\text { Penney and Racek (1968); Manconi and } \\
\text { Pronzato (2007) }\end{array}$ & Thailand & 1 & & $\begin{array}{l}\text { Uncommon; needs } \\
\text { revision }\end{array}$ \\
\hline & E. tinei & 1 & $\begin{array}{l}\text { Penney and Racek (1968); Manconi and } \\
\text { Pronzato (2007) }\end{array}$ & Philippines & & 1 & Needs revision \\
\hline \multirow[t]{3}{*}{$\begin{array}{l}\text { Metania } \\
3 \text { species }\end{array}$} & M. pottsi & 1 & Manconi and Pronzato $(2007,2009)$ & & & 1 & $\begin{array}{l}\text { Recent detailed } \\
\text { description in } \\
\text { Manconi and } \\
\text { Pronzato (2009) }\end{array}$ \\
\hline & M. vesparia & 1 & $\begin{array}{l}\text { Penney and Racek (1968); Manconi and } \\
\text { Pronzato (2007) }\end{array}$ & & & 1 & $\begin{array}{l}\text { High variable } \\
\text { morphology }\end{array}$ \\
\hline & M. vesparioides & 1 & $\begin{array}{l}\text { Penney and Racek (1968); Manconi and } \\
\text { Pronzato (2007) }\end{array}$ & & 1 & & $\begin{array}{l}\text { Very close to } \\
\text { M. vesparia }\end{array}$ \\
\hline $\begin{array}{l}\text { Oncosclera } \\
1 \text { species }\end{array}$ & O. asiatica & 1 & Manconi et al. (2012) & Thailand & 1 & & Recently described \\
\hline \multirow[t]{4}{*}{$\begin{array}{l}\text { Radiospongilla } \\
4 \text { species }\end{array}$} & R. cerebellata & 2 & $\begin{array}{l}\text { Penney and Racek (1968); Manconi and } \\
\text { Pronzato (2007) }\end{array}$ & & 2 & & $\begin{array}{l}\text { Recent detailed } \\
\text { description in } \\
\text { Jakhalekar and Ghate } \\
\text { (2013); potential } \\
\text { species complex }\end{array}$ \\
\hline & R. crateriformis & 2 & $\begin{array}{l}\text { Penney and Racek (1968); Manconi and } \\
\text { Pronzato }(2005,2007)\end{array}$ & & 1 & 1 & $\begin{array}{l}\text { Widespread; high } \\
\text { variable } \\
\text { gemmulosclere } \\
\text { morphology; } \\
\text { potential species } \\
\text { complex }\end{array}$ \\
\hline & R. indica & 2 & $\begin{array}{l}\text { Penney and Racek (1968); Manconi and } \\
\text { Pronzato (2007) }\end{array}$ & & & 2 & Typical megascleres \\
\hline & R. philippinensis & 1 & Manconi and Pronzato (2007) & & & 1 & Needs revision \\
\hline
\end{tabular}


Tab. 2. Continued from previous page.

\begin{tabular}{|c|c|c|c|c|c|c|c|}
\hline Genera & Species & Records & Species validation & $\begin{array}{l}\text { SE-Asia } \\
\text { endemics }\end{array}$ & Continental & Insular & Remarks \\
\hline \multirow[t]{2}{*}{$\begin{array}{l}\text { Spongilla } \\
1 \text { species }\end{array}$} & S. alba & 1 & $\begin{array}{l}\text { Penney and Racek (1968); Manconi and } \\
\text { Pronzato (2007) }\end{array}$ & & 1 & & $\begin{array}{l}\text { Widespread; } \\
\text { potential species } \\
\text { complex; needs } \\
\text { revision }\end{array}$ \\
\hline & Spongilla sp. & 1 & & & 1 & & \\
\hline Stratospongilla & S. clementis & 1 & $\begin{array}{l}\text { Penney and Racek (1968); Manconi and } \\
\text { Pronzato }(2002,2007)\end{array}$ & & & 1 & Needs revision \\
\hline \multirow[t]{2}{*}{3 species } & S. indica & 1 & $\begin{array}{l}\text { Penney and Racek (1968); Manconi and } \\
\text { Pronzato (2007) }\end{array}$ & & 1 & & $\begin{array}{l}\text { Typical } \\
\text { megascleres }\end{array}$ \\
\hline & S. sumatrana & 1 & $\begin{array}{l}\text { Penney and Racek (1968); Manconi and } \\
\text { Pronzato (2007) }\end{array}$ & & & 1 & Several ecomorphs \\
\hline \multirow[t]{2}{*}{$\begin{array}{l}\text { Trochospongilla } \\
2 \text { species }\end{array}$} & T. latouchiana & 4 & $\begin{array}{l}\text { Penney and Racek (1968); Manconi and } \\
\text { Pronzato (2007) }\end{array}$ & & 2 & 2 & $\begin{array}{l}\text { Recent detailed } \\
\text { description in } \\
\text { Jakhalekar and Ghate } \\
\text { (2013) }\end{array}$ \\
\hline & T. phillottiana & 2 & $\begin{array}{l}\text { Penney and Racek (1968); Manconi and } \\
\text { Pronzato (2007) }\end{array}$ & & 2 & & Needs revision \\
\hline $\begin{array}{l}\text { Umborotula } \\
1 \text { species }\end{array}$ & U. bogorensis & 3 & $\begin{array}{l}\text { Penney and Racek (1968); Manconi and } \\
\text { Pronzato }(2002,2007)\end{array}$ & & 2 & 1 & Needs revision \\
\hline
\end{tabular}

SE, Southeast.

sponges determining the suspension of spicules in the water column as reported from South America (Araguaia river) (Volkmer-Ribeiro et al., 2006, 2008; Mendes et al., 2009).

Key to families and genera of Spongillina from Southeast Asia

(1) Gemmules (resting stages) present . .2

- Gemmules absent ..................................................4

(2) Gemmular theca with pneuma absent to scantly developed. Gemmuloscleres, when present, as tangentially arranged, short, irregular strongyles; gemmules when present in the basal portion. Skeletal network typically multispicular alveolate-reticulate, scanty spongin; megascleres strongyles to oxeas; microscleres rarely recorded

Potamolepidae

- Gemmular theca bi- to tri-layered (pneumatic layer generally present) . ....3

(3) Gemmuloscleres as oxeas, strongyles, birotules, pseudobirotules, botryoidal, club-like (radially to tangentially arranged); skeletal network paucispicular, irregularly reticulate; megascleres oxeas to strongyles, smooth/variably ornamented; microscleres usually present

Spongillidae

- Gemmuloscleres tubelliform, parmuliform, pseudobirotules (almost exclusively radially arranged); skeletal network typically multispicular alveolate-reticulate with scanty spongin; smooth to variably ornamented megascleres (oxeas to strongyles); microscleres usually present
Metaniidae

(4) Lubomirskiidae, Metschnikowiidae, Malawispongiidae, Spongillina incertae sedis (not reported at present from SE Asia).

\section{Family Spongillidae Gray, 1867}

(1) Birotules and pseudobirotules present .................5

- $\quad$ Birotules and pseudobirotules absent ....................2

(2) Presence of microscleres and/or gemmuloscleres (not pseudobirotules and/or birotules) ........................4

(4) Microscleres absent; megascleres are spiny oxeas; gemmuloscleres are spiny strongyles radially oriented ..

Radiospongilla

- Microscleres absent; megascleres are spiny and smooth oxeas to strongyles; gemmuloscleres are spiny oxeas of two morphologies: strongyles stout, short and spined, tangentially embedded in the outer layer of gemmular theca; spiny oxeas abruptly pointed, radially arranged in between the inner and outer layer

Stratospongilla

- Microscleres absent; megascleres smooth oxeas; gemmuloscleres oxeas to strongyles, usually smooth, tangentially arranged in the gemmular theca ........Eunapius

- Microscleres spiny oxeas; megascleres smooth oxeas; gemmuloscleres, when present, spiny oxeas to strongyles often very curved Spongilla (5) Birotules with rotules showing smooth edges, pseudobirotules absent ...6 

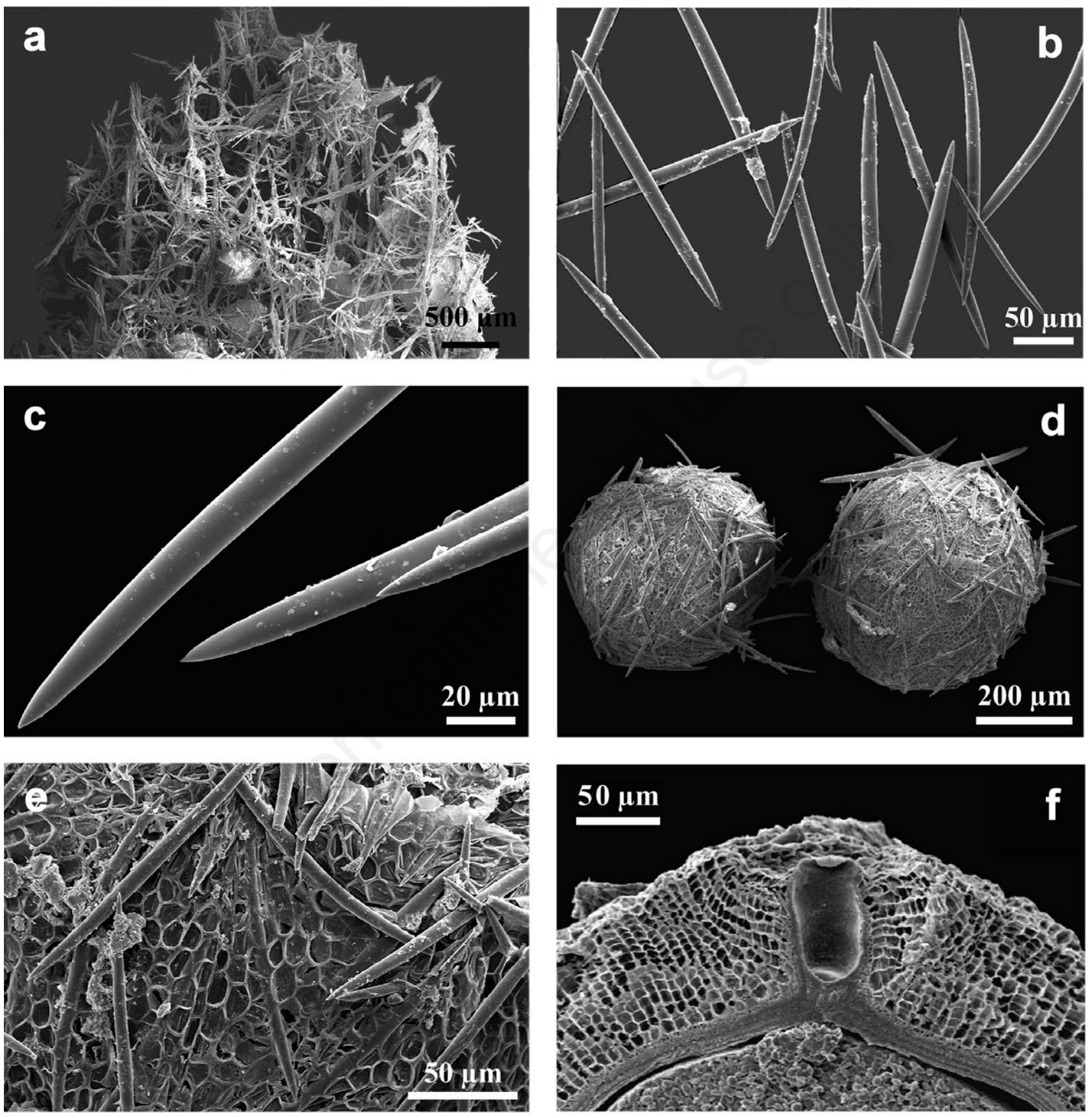

Fig. 2. Eunapius carteri from the Lower Mekong hydrographic basin (Khon Kaen province, Northeast-Thailand), apparently cosmopolitan, is at present the most common species in the Southeast Asia. a) Skeletal network with scattered subspherical gemmules; b, c) oxeas (megascleres) of the skeletal network; d) gemmules with surface armed by tangential gemmuloscleres; e) close up on the gemmule surface with ornamentations of polygonal compact spongin and some gemmuloscleres (microxeas) on the outer gemmular layer); f) cross section of a gemmule showing the multilayered theca with the foramen, the thick pneumatic layer of chambered spongin, and the inner layer of compact spongin protecting a dense mass of staminal cells in the internal chamber. 
- $\quad$ Birotules with spiny rotules and indented edges generally associated with pseudobirotules 7 (6) Microscleres absent; megascleres are oxeas very spiny; gemmuloscleres are smooth birotules radially arranged ..... Trochospongilla

(7) Birotules and/or pseudobirotules are present, exclusively as microscleres ....8

- $\quad$ Birotules and/or pseudobirotules are present, exclusively as gemmuloscleres ...................................... 9

(8) Gemmuloscleres spiny/smooth strongyles tangentially arranged in the gemmular theca; megascleres smooth to microgranulate strongyles to oxeas; microscleres pseudobirotules usually with smooth shaft

Corvospongilla

(9) Gemmuloscleres birotules of a single morphology

10

(10) Birotules with a short (usually less than the rotule diameter) shaft 11

- $\quad$ Birotules with a long spiny shaft (2-3 times the rotule diameter) 12

(11) Gemmuloscleres are birotules with a short shaft and rotules of identical diameter; microscleres are absent; megascleres are microspined and/or smooth oxeas

Ephydatia

(12) Gemmuloscleres are birotules with long spiny shaft; microscleres are absent; megascleres are microspined and rarely smooth oxeas

Umborotula

Gemmuloscleres are birotules with a long spiny shaft; microscleres range from acanthoxeas to typical $\mathrm{eu}$ asters with spiny tips; megascleres are smooth oxeas ....

Dosilia

(13) Corvoheteromeyenia, Heterorotula, Pectispongilla, Uruguayella, Saturnospongilla, Heteromeyenia, Racekiela, Pachyrotula, Anheteromeyenia, Nudospongilla, Duosclera, Sanidastra (not reported at present from SE Asia).

\section{Family Metaniidae Volkmer-Ribeiro, 1986}

(1) Gemmuloscleres of a single tubelliform morph, radially arranged with larger rotule embedded in the inner layer of the gemmular theca; microscleres strongyles smooth to spiny; megascleres oxeas to strongyles, smooth to spiny Metania

(2) Drulia, Acalle, Corvomeyenia, Houssayella (not reported at present from SE Asia).

\section{Family Potamolepidae Brien, 1967}

(1) Megascleres stout oxeas to strongyles, rarely bearing tubercles/granules, with acerate tips; microscleres absent; gemmules when present, with gemmuloscleres tangentially arranged; gemmuloscleres highly variable from true strongyles to irregular ovoid strongyles, from smooth to ornamented with short spines/tubercles dense at tips ....
.... Oncosclera

(2) Sterrastrolepis, Echinospongilla, Potamolepis, Potamophloios, Uruguaya (not reported at present from SE Asia).

\section{DISCUSSION}

\section{Global diversity of Spongillina}

At a global level, the biodiversity assessments, although in a dynamic status and continuously under revision and updating, focus at present on 7 families, 47 genera, and 237 species of freshwater sponges (Manconi and Pronzato, 2013; Van Soest et al., 2013). The Neotropical region shows the highest species richness of Spongillina (72 species) followed by Palaearctic (65 species), Afrotropical (52 species), Oriental (39 species), Australian (34 species), Nearctic (31 species), and Pacific (7 species) regions; no freshwater sponges are reported from the Antarctica. Taxonomic richness values in the Oriental region are not among the highest (Manconi and Pronzato, 2013), although this may be related to the small size of the region.

\section{Biogeography of Spongillina in Southeast Asia}

A comparison among different areas within the Oriental region, shows that the Indian subregion is less rich (23 species) than SE Asia (26 species); in the latter, the continental species (13 species) slightly overcome the insular ones ( 9 species). Conversely, the Indian subregion hosts a larger number of endemic taxa (ten species) when compared to SE Asia (4 species). The present diversity values doubtlessly appear destined to increase with further research on unexplored and poorly sampled areas, and from molecular analyses focused mainly on cosmopolitan/widespread species that are presently assumed to consist of cryptic species complexes (Tab. 2).

The major affinities of the Oriental region are with the Australian (7 shared species) and Afrotropical regions (5 shared species). Focusing on SE Asia, 6 species are exclusively Oriental and another 6 are cosmopolitan, although the latter probably represent species complexes. The species shared with the other biogeographic regions are 7 with the Afrotropical region, 6 with the Australian region, and 4 with the Palaearctic region.

The Oriental-Australian boundary is one of most studied and discussed regions from a biogeographic point of view; the presence of Wallacea represents an area of overlapping and vagueness in still unsolved distribution patterns. As for freshwater sponges, by simply considering the Wallace (1859) or the Weber lines (1937) in alternative, it is possible to include or exclude for example Sulawesi (Celebes) in the Oriental region; this involves the inclusion or exclusion of other two species of freshwater sponges viz. Nudospongilla vasta (Weltner, 1901) from Sulawesi and 

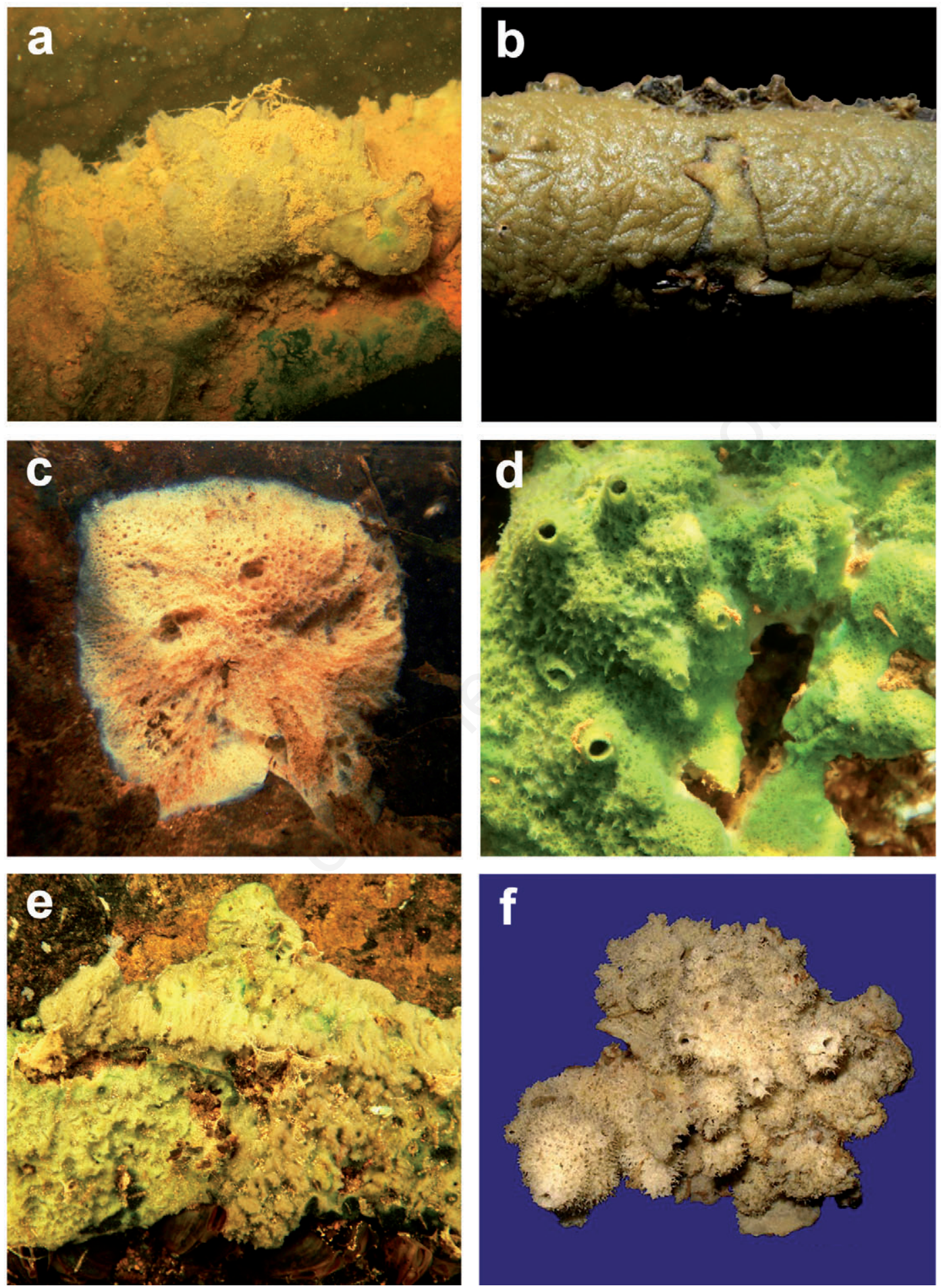

Fig. 3. Freshwater sponges from the Lower Mekong hydrographic basin (Khon Kaen province, Northeast-Thailand) in their natural surroundings (a-e). a) Corvospongilla siamensis from shallow water; b) Oncosclera asiatica, type specimens in vivo from type locality near Ubolratana dam, Pong river; c) Radiospongilla sp. with encrusting growth form; d) C. siamensis with symbiotic algae, as indicated by brilliant green, growing on a buoy in well illuminated habitat from type locality near Ubolratana dam, Pong river; e) Corvospongilla sp. growth form associated to bivalves, in running water on rock; f) C. siamensis dry holotype from type locality near Ubolratana dam, Pong river. 
Indonesia, and Pachidictyum globosum Weltner, 1901 from Sulawesi, increasing the endemicity level of the area in the case of preference of the Weber line.

\section{Biodiversity hotspots}

Although SE Asia is considered a biodiversity hotspot for many vertebrate and invertebrate taxa (Myers et al., 2000), knowledge on freshwater sponges in this area seems poor and scarcely reported. The famous axiom, repeatedly reported by biogeographers reading The distribution and abundance of species characteristic of a geographical region is directly proportional to the distribution and abundance of researchers who work and have worked in the same area seems to be confirmed (Manconi and Pronzato, 2007). Indeed, a high number of species (18 out of 26) is reported only once from this area. Moreover, in same cases findings are very old and not confirmed by recent field campaigns. The evidence that during the last investigations (Manconi et al., 2012; Ruengsawang et al., 2012) on a small area of the Lower Mekong hydrographic basin new species have been discovered, shows how the freshwater sponge diversity is dramatically underestimated and probably related to undersampling. The recent discovery of $O$. asiatica from Northeastern Thailand (Pong river enlarges the disjunct geographic range of the genus Oncosclera Volkmer-Ribeiro, 1970 to the Oriental region and represents the single record from the entire continental Asia (Manconi et al., 2012). On the other hand, the discovery of $C$. siamensis from Northeastern Thailand extends the easternmost range of the disjunct range in the Oriental region of the genus Corvospongilla Annandale, 1911.

\section{Endemicity, cosmopolitanism and species rarity}

Eunapius potamolepis and Eunapius tinei are the two historical SE-Asiatic endemics being described from Lampam (Thailand) by Annandale in 1918 and from Philippines by Gee in 1932, respectively. These two species were no longer reported and are still known only for their type localities. Penney and Racek (1968), who studied the available material (slides) of the two species, expressed many doubts about their taxonomic status. Also, the illustrations of the two species, lacking detail (Fig. 4) from these last authors, did not show convincing distinctions.

This situation is very common for freshwater sponge species, e.g. although 58 species have been hitherto recorded from African inland water (Manconi and Pronzato, 2009), a large number of them (25) is known only for one sample from the type locality and is not reported over periods longer than 50 or 100 years. Little material available, old and incomplete descriptions and illustrations, absence of any other findings and confirmations, make taxonomic and zoogeographical studies on the Spongillina extremely problematic. Nevertheless, pauci sed indomita scientists continue to persist in their studies.

The life cycle encompassing phases of cryptobiosis further complicates the study of the geographic distribution of Spongillina, as well as the fragmentary nature and paucity of space-time data.

As regards cosmopolitanism of freshwater sponges recorded from SE Asia, and in general the Oriental region, the presence of 6 (out of 26; Tab. 1) cosmopolitan/widespread species suggests the need of investigations in depth to ascertain if they belong to species complex.

The dataset indicates that species richness of freshwater sponges is commonly underestimated in tropical latitudes where new findings often correspond to the discovery of new secies as recently focused in Thailand (Manconi et al., 2012; Ruengsawang et al., 2012). Information from other countries of SE Asia is needed for a better understanding of diversity and geographic distribution. More investigations by field surveys in unexplored and/or poorly sampled areas should reveal higher values of taxonomic richness highlighting biogeographic patterns at family/genus/species levels. Cooperative research network involving Thai, Laotian and Italian teams was set up to contribute and extend knowledge on taxonomy, ecology and biotechnological potentialities of these neglected filter feeders playing a key role in water purification and biomass production in both lentic and lotic ecosystems of the tropics.

\section{CONCLUSIONS}

Protection of these sessile invertebrates will support the conservation of the key resource represented by freshwater
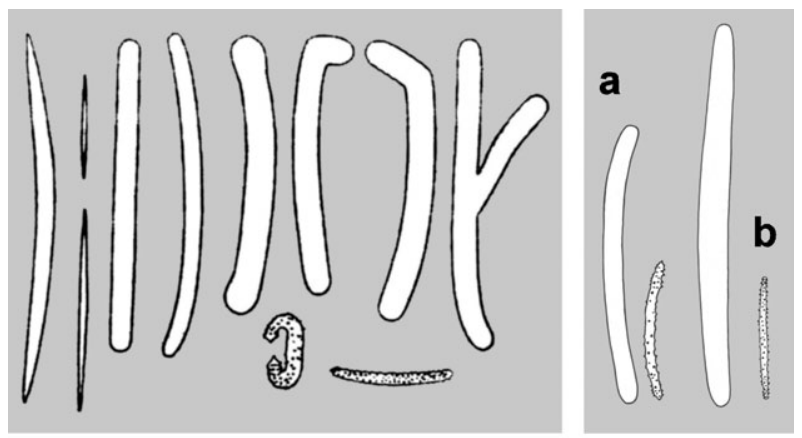

Fig. 4. Spicular complement of Eunapius potamolepis (left and a) and Eunapius tinei (right b). These species are endemic to the Southeast Asia (Thailand and Philippines, respectively) and were discovered in the first half of the $20^{\text {th }}$ century. Left panel modified from the original low quality drawing by Annandale (1918); right panel modified from the original drawing by Penney and Racek (1968). 


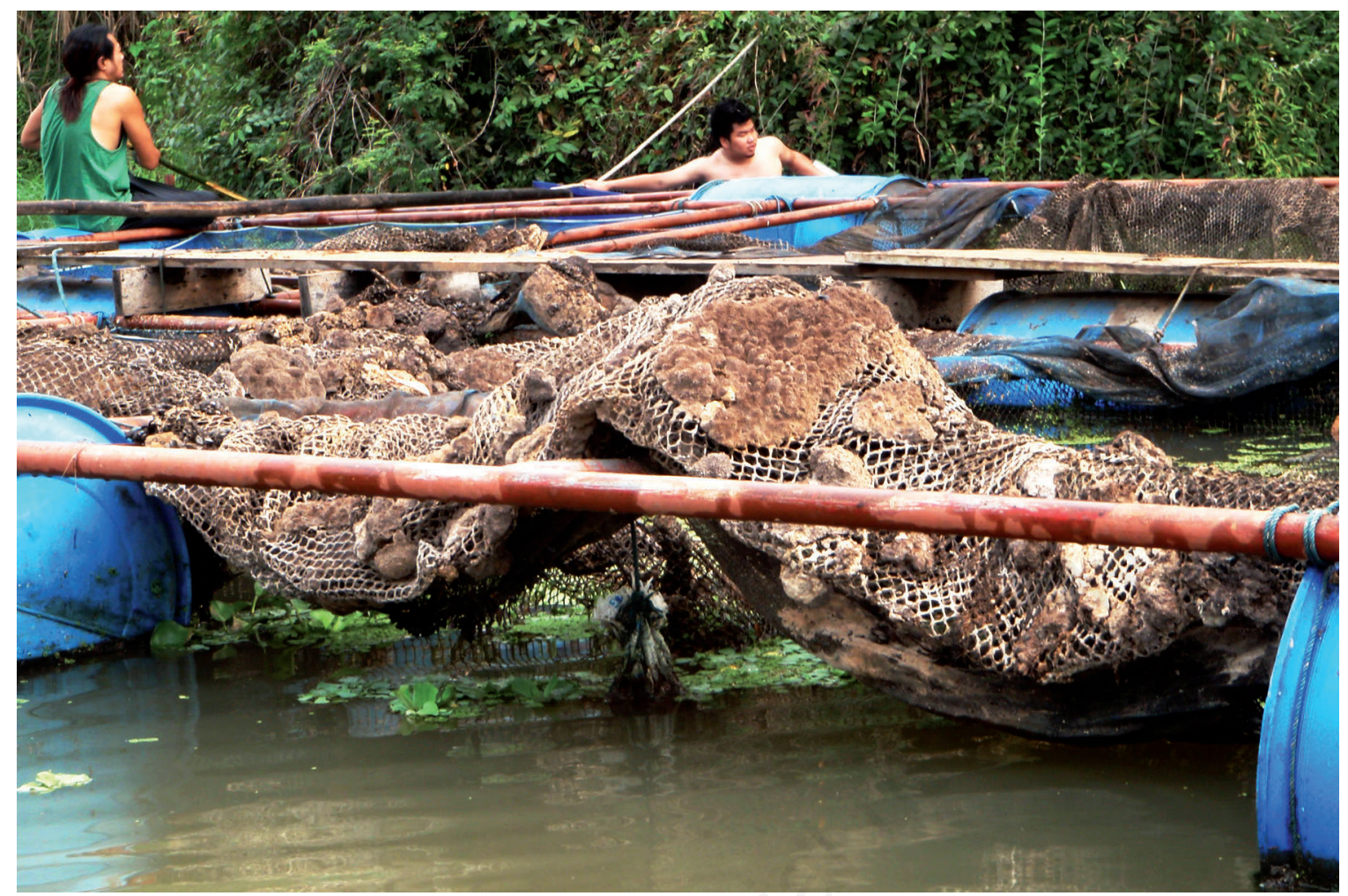

Fig. 5. Massive specimens of Corvospongilla sp. on nets from Thailand (Lower Mekong hydrographic basin).

bodies for the future at a global level. From an ecological viewpoint, sponges perform key functional roles in ecosystems. Pumping activity by their aquiferous system helps to circulate the water column, particularly in lentic conditions, also favouring particulate and dissolved organic trapping. Sponges also provide a living refuge for a wide array of organisms, and symbiosis with autotrophic microorganisms contributes to primary production. Moreover, their siliceous skeleton contributes to the formation of sediments after the sponge's death to form spiculites beds.

Basic research coupled with a sustainable management planning of this bioresource will result in a valorisation process of their performances as biofilters, as source of bioactive and biomimetic molecules, and as suitable microhabitats and centres of biological associations hosting a wide array of organisms belonging to several phyla.

\section{ACKNOWLEDGMENTS}

We are grateful to the staff of the Department of Biology and Applied Taxonomic Research Center, Faculty of Science, Khon Kaen University, Thailand, for facilitating this study. We also thank Boonsong Kongsook for his valuable technical assistance in SEM micrography, Chawalit Wongsanorasaet for his kind logistic support and Paiboon
Getwongsa, Prayut Udonphimai for their field assistance, and Dr. Amir Shah Ruddin Md Sah for valuable reference from Malaysia. Nisit Ruengsawang and Renata Manconi were supported by the Office of the Higher Education Commission, Thailand. Funds to Renata Manconi were partly provided by the Italian Ministero dell'Università e della Ricerca Scientifica e Tecnologica (MIUR-PRIN) and the Fondazione Banco di Sardegna. We acknowledge the Organizing Committee of FISA Conference, and the Maha Sarakham University and Khon Kaen University for participation in the Proceedings.

\section{REFERENCES}

Annandale N, 1909. Freshwater sponges in the collection of the United States National Museum. I. Specimens from the Philippines and Australia. Proc. U. S. Natl. Mus. 36:627632.

Annandale N, 1911. Freshwater sponges, hydroids and polyzoa. Porifera, p. 27-126, 241-245. In: A.E. Shipley (ed.), Fauna of British India, including Ceylon and Burma. Taylor \& Francis.

Annandale N, 1915. Fauna of the Chilka Lake. Sponges. Mem. Indian Mus. 5:21-54.

Annandale N, 1918. Zoological results of a tour in the Far East. II. Freshwater sponges from Japan, China, and the Malay Peninsula. Memoirs of the Asiatic Society of Bengal 6:199-216. 
Arndt W, 1926. [Die spongillidenfauna Europas]. [Article in German]. Arch. Hydrobiol. 17:337-365.

Banarescu P, 1995. Zoogeography of fresh waters. 3. Distribution and dispersal of freshwater animals in Africa, Pacific Areas and South America. AULA-Verlag, Wiesbaden: 616 pp.

Bowerbank JS, 1863. A monograph of the Spongillidae. P. Zool. Soc. Lond. 1863:440-472.

Carter HJ, 1881. History and classification of the known species of Spongilla. Ann. Mag. Nat. Hist. 5:77-107.

Erpenbeck D, Weier T, de Voogd NJ, Wörheide G, Sutcliffe P, Todd JA, Michel E, 2011. Insights into the evolution of freshwater sponges (Porifera: Demospongiae: Spongillina): barcoding and phylogenetic data from Lake Tanganyika endemics indicate multiple invasions and unsettle existing taxonomy. Mol. Phylogenet. Evol. 61:231-236.

Evans KL, Kitting CL, 2010. Documentation and identification of the one known freshwater sponge discovered in the California Delta. Open Mar. Biol. J. 4:82-86.

Gaino E, 2011. Overview of Porifera, p. 1-53. In: M. Pansini, R. Manconi, and R. Pronzato (eds.), Porifera. I. Calcarea, Demospongiae (partim), Hexactinellida, Homoscleromorpha. Il Sole 24 Ore Edagricole.

Gee NG, 1930. Notes on the freshwater sponges from the Dutch East Indies. II. Descriptions. Treubia 12:67-114.

Gee NG, 1931. A contribution towards an alphabetical list of the known freshwater sponges. Peking Nat. Hist. Bull. 5:31-52.

Gee NG, 1932a. Spongilla carteri and its varieties. The Trustees, Calcutta: 10 pp.

Gee NG, 1932b. The known freshwater sponges. Peking Nat. Hist. Bull. 6:25-51.

Hu JM, Zhao YX, Chen JJ, Miao ZH, Zhou J, 2009. A new spongilipid from the freshwater sponge Spongilla lacustris. Bull. Korean Chem. Soc. 30:1170-1172.

Jakhalekar SS, HV Ghate, 2013. A note on five freshwater sponges (Porifera: Spongillina:Spongillidae) from Pune, Maharashtra, India. J. Threat. Taxa 5:4392-4403.

Linnaeus C, 1759. [Systema naturae per regna tria naturae, secundum classes, ordines, genera, species, cum characteribus, differentiis, synonymis, locis. II. Editio decima, reformata]. [Book in Latin]. Laurentii Salvii, Stockholm: 561 pp.

Manconi R, 2008. The genus Ephydatia (Spongillina: Spongillidae) in Africa: a case of Mediterranean vs. southern Africa disjunct distribution. Biogeographia 29:19-28.

Manconi R, Pronzato R, 2000. Rediscovery of the type material of Spongilla lacustris (L., 1759) from the Linnean Herbarium. Ital. J. Zool. 67:89-92.

Manconi R, Pronzato R, 2002. Spongillina n. subord. Freshwater sponges. Lubomirskiidae, Malawispongiidae n. fam., Metaniidae, Metschnikowiidae, Palaeospongillidae, Potamolepidae, Spongillidae, p. 921-1019. In: J.N.A Hooper and R.W.M. Van Soest (eds.), Systema Porifera. A guide to the classification of sponges. I. Kluwer Academic/Plenum Publishers.

Manconi R, Pronzato R, 2004. The genus Corvospongilla Annandale (Haplosclerida, Spongillina, Spongillidae) with description of a new species from eastern Mesopotamia, Iraq. Arch. Hydrobiol. 151:161-189.

Manconi R, Pronzato R, 2005. Freshwater sponges of the West Indies: discovery of Spongillidae (Haplosclerida, Spongillina) from Cuba with biogeographic notes and a checklist for the Caribbean area. J. Nat. Hist. 39:3235-3253.
Manconi R, Pronzato R, 2007. Gemmules as a key structure for the adaptive radiation of freshwater sponges: a morphofunctional and biogeographical study, p. 61-77. In: M.R. Custódio, G. LôboHajdu, E. Hajdu, and G. Muricy (eds.), Porifera research: biodiversity, innovation and sustainability. Museu Nacional Rio de Janeiro ed.

Manconi R, Pronzato R, 2008. Global diversity of sponges (Porifera: Spongillina) in freshwater. Hydrobiologia 595:27-33.

Manconi R, Pronzato R, 2009. Atlas of African freshwater sponges. Studies in Afrotropical Zoology, 295. Royal Museum for Central Africa ed., Tervuren: 214 pp.

Manconi R, Pronzato R, (2013). Phylum Porifera, Chapter 8. In: J.H. Thorp, D.C. Rogers, and K. Tockner (eds.), Thorp and Covich's freshwater invertebrates, $4^{\text {th }} \mathrm{ed}$. Elsevier (in press).

Manconi R, Ruengsawang N, Ledda FD, Hanjavanit C, Sangpradub N, 2012. Biodiversity assessment in the Lower Mekong basin: first record of the genus Oncosclera (Porifera: Spongillina: Potamolepidae) from the Oriental Region. Zootaxa 3544:41-51.

Masuda Y, 2004. A study of the freshwater sponges, Eunapius carteri (Bowerbank, 1863), Eunapius crassissimus (Annandale, 1907), and Trochospongilla latouchiana Annandale, 1907, Spongillidae (Demospongiae) from Lake Tonle Sap in Cambodia. Kawasaki Med. J. 30:47-62.

Meixner MJ, Lüter C, Eckert C, Itskovich V, Janussen D, von Rintelen T, Bohne AV, Meixner JM, Hess WR, 2007. Phylogenetic analysis of freshwater sponges provide evidence for endemism and radiation in ancient lakes. Mol. Phylogenet. Evol. 45:875-886.

Mendes MO, Moraes MAP, Renoiner EIM, Dantas MHP, Lanzieri TM, Fonseca CF, Luna EJA, Hatch DL, 2009. Acute conjunctivitis with episcleritis and anterior uveitis linked to adiaspiromycosis and freshwater sponges, Amazon Region, Brazil 2005. Emerg. Infect. Dis. 15:633-639.

Myers N, Mittermeier RA, Mittermeier CG, da Fonseca GAB, Kent J, 2000. Biodiversity hotspots for conservation priorities. Nature 403:853-858.

Ohtaka A, Narita T, Kamiya T, Katakura H, Araki Y, Im S, Chhay R, Tsukawaki S, 2011. Composition of aquatic invertebrates associated with macrophytes in Lake Tonle Sap, Cambodia. Limnology 12:137-144.

Penney JT, 1960. Distribution and bibliography (1892-1957) of the freshwater sponges. University of South Carolina Publ., Columbia: 97 pp.

Penney JT, Racek AA, 1968. Comprehensive revision of a worldwide collection of freshwater sponges (Porifera: Spongillidae). Bull. U. S. Nat. Mus. 272:1-184.

Pisera A, 2004. What can we learn about siliceous sponges from palaeontology, p. 55-69. In: M. Pansini, R. Pronzato, G. Bavestrello, and R. Manconi (eds.), Sponge science in the new millennium. Officine Grafiche Canessa ed.

Pisera A, Saez A, 2003. Paleoenvironmental significance of a new species of freshwater sponge from the Late Miocene Quillagua formation (N Chile). J. S. Am. Earth Sci. 15:847852.

Potts E, 1887. Contribution towards a synopsis of the American forms of fresh-water sponges with descriptions of those named by other authors and from all parts of the world. Monograph. P. Acad. Nat. Sci. Phila. 39:158-279. 
Pronzato R, Manconi R, 1994a. Adaptive strategies of sponges in inland waters. B. Zool. 61:395-401.

Pronzato R, Manconi R, 1994b. Life history of Ephydatia fluviatilis: a model for adaptive strategies in discontinuous habitats, p. 327-331. In: R.W.M. Van Soest, T.M.G. Van Kempen, and J.C. Braekman (eds.), Sponges in time and space. Balkema ed.

Pronzato R, Manconi R, 1995. Long-term dynamics of a freshwater sponge population. Freshwater Biol. 33:485-495.

Pronzato R, Manconi R, 2001. Atlas of European freshwater sponges. [Annali del Museo civico di Storia naturale di Ferrara]. [Journal in Italian] 4:3-64.

Racek AA, 1969. The freshwater sponges of Australia (Porifera: Spongillidae). Aust. J. Mar. Fresh. Res. 20:267-310.

Ruengsawang N, Hanjavanit C, Sangpradub N, Manconi R, 2012. Biodiversity assessment of the Lower Mekong Basin: a new species of Corvospongilla (Porifera: Spongillina: Spongillidae) from Thailand. Zootaxa 3320:47-55.

Schindler TH, Wuttker M, Poschmann M, 2008. Oldest record of freshwater sponges (Porifera: Spongillina) spiculite finds in the Permo-Carboniferous of Europe. Palaeontol. Z. 82:373-384.

Schröder K, 1935. [Spongillidenstudien. VII. Susswasserschwamme von Neuseeland, Borneo und Madagaskar]. [Article in German]. Zool. Anz. 109:97-106.

Soota TD, 1991. Freshwater sponges of India. Zoological Survey of India ed., Calcutta: 116 pp.

Van Soest RWM, Boury-Esnault N, Hooper JNA, Rützler K, de Voogd NJ, Alvarez de Glasby B, Hajdu E, Pisera AB, Manconi R, Schoenberg C, Janussen D, Tabachnick KR, Klautau
M, Picton B, Kelly M, Vacelet J, Dohrmann M, Díaz MC, 2013. World porifera database. Available from: http://www. marinespecies.org/aphia.php? $\mathrm{p}=$ taxdetails $\& \mathrm{id}=558$

Volkmer-Ribeiro C, Batista TCA, Melóo MGG, Fonseca-Gessner AA, 2008. Anthropically dislodged assemblages of sponges (Porifera: Demospongiae) in the River Araguaia at Araguatins, Tocantins, Brazil. Acta Limnol. Bras. 20:16975. Available from: http://www.ablimno.org.br/acta/pdf/acta 20 vol2 10.pdf

Volkmer-Ribeiro C, Costa PRC, 1993. Redescription of the Oriental and Australian species of the genus Metania Gray, 1867 (Porifera: Metaniidae). Iheringia Ser. Zool. 74:81-101.

Volkmer-Ribeiro C, Lenzi HL, Oréfice F, Pelajo-Machado M, Alencar LM, Fonseca CF, 2006. Freshwater sponge spicules: a new agent of ocular pathology. Mem Inst. Oswaldo Cruz 101:899-903.

Vorstman AG, 1927. [Soetwatersponsen van West Java]. [Article in Dutch]. Tropische Natuur 16:181-184.

Vorstman AG, 1928. [Sponsen unit eenige plassen en mercy in Oust-Java]. [Article in Dutch]. Tropische Natuur 17:113-117.

Weber M, 1890. [Spongillidae des Indischen Archipels]. [Article in German]. Zoologische Ergebnisse einer Reise nach Niederlandisch Ost-Indien 1:30-47.

Weltner W, 1895. [Spongillidenstudien III. Katalog und verbreitung der bekannten susswasserschwamme]. [Article in German]. Arch. Naturgesch. 61:114-144.

Weltner W, 1913. [Süsswasserschwämme (Spongillidae) der Deutschen Zentralafrika Expedition 1907-1908]. [Article in German]. Wissenschaftliche Ergebnisse der Deutschen Antarktischen Expedition 1938-39, Hamburg 12:475-485. 